\title{
ComparingDebt Purchase with Some Islamic Contracts
}

\author{
Zeynab Adabi ${ }^{1}$, Alireza Lotfi ${ }^{1 *}$, Saleh Eynollahi ${ }^{2}$ \\ ${ }^{I}$ Department of low, ArdabilBranch, Islamic Azad University,Ardabil, Iran \\ ${ }^{2}$ Department of low, TabrizBranch, Islamic Azad University, Tabriz,Iran
}

\begin{abstract}
Debt purchase in a contract which due to that a person buys debtors debt, less than the real amount by cash. Banks can buy applicants business exchanges to create necessary facilities for all economical sections. Documents and business exchanges are valuable papers that indicate the real debt of applicant. Bank should make sure of reality and cash ability of debt before buying it. Contract's performative instruction of debt purchase will be made by central bank and confirmed by money and credit council. Islamic banking system has offered some supportive services in order to provide peoples welfare and keeps the economy going which in this article we intent to compare them with debt purchase.
\end{abstract}

Keywords: Debt purchase, Money loaned without interest, Murabaha, Islamic contracts

\section{INTRODUCTION}

In Islam point of view, receipt and payment of interest is banned, so banking should be done interestfree, and Islam suggests some methods to replace interest and economic institutions based on it, among which includes Islamic contracts pointed out as an efficient way. Public welfare fulfillment and economic justice establishment are goals of Islamic economy system and doubtlessly performing this system deletes the poverty of society. One of the basic steps to achieve this goal is to change the banking system and remove interest out of it and use Islamic contracts based on the banking system.

Reba is an interest or profit which is fixed, is the major cause of poverty and level differences insociety.Banking system using Reba causes bankruptcy and increases poverty and unemployment. Moreover it brings inflation which increases poverty.

Debt purchase contract with fifth development approval in 2010 joined written contracts of Reba-free banking and money and credit council approved these three contracts performance regulation: Estesna, Morahebe and debt purchase.

Debt purchase contract is type of contract that has performance instruction but stated as an independent Rebafree contract in banking operations and problems of production units ,services and trades will be solved.by performing new standards of this contract. As it said before cash purchase added to banking system in 2011 for the first time and now can be operated as a banking contract. Debt purchase contract is religious and legal in nature.(MolaKarimi 2011)

\section{Chapter 1:Gharzolhasaneh}

According to $648^{\text {th }}$ item of civil law and $15^{\text {th }}$ item of third chapter of Reba-free banking regulation Gharzolhasaneh is a contract which according to it a person gives a certain amount of money to other and the other one should pay back the same amount kind and quality and in the case of being unable to pay the exact amount back he should pay the price of it. (Business law fascicle 2009).

\section{A)Examples of Gharzolhasaneh}

According to $16^{\text {th }}$ item of third chapter of reba-free banking law Gharzolhasane is given to items below:

A) To obtain tools and other necessary facilities to create job opportunities in cooperative company for whom aren't able to do so.

B) Help to increase production particularly agriculture and industry.

C) Obtain necessary needs

Gharzolhasane which is granting to part $\mathrm{A}$ is special for making job opportunities given to cooperative companies except business and mining.

In part B: Gharzolhasane is granted to workshops and production units in small cities and villages to help increase the production and the items below:

1) To prevent the stop of workshops and units in small cities and villages.

2) Restart the closed workshops and units.

3) Develop small workshops and units. 
4) To create small workshops and units in small cities and countries.

5) When obtaining workshop or unit necessary needs is not possible using other facilities.

6) Creating some facilities to whom work on agriculture lands.(Hedayati 2002).

B)MaximumGharzolhasaneh facilities

1) The maximum amount of gharzolhasaneh granted by banks is $10 \%$ of all provided in each year.

2) The maximum amount of Gharzolhasane granted to cooperative companies and production units is 5

Rials and 2 million Rials to people.

\section{Gharzolhasaneh refund duration:}

1) Gharzolhasaneh refund duration for companies is at most 5 years

2) Gharzolhasaneh refund duration for people is at most 3 years.

3) Gharzolhasaneh's installment will be monthly, every 3 month, 6 month or annual or one time.

\section{Second chapter: leasing}

$10^{\text {th }}$ and $11^{\text {th }}$ items and part A of $13^{\text {th }}$ item of $3^{\text {rd }}$ chapter in Reba-free banking regulations are about leasing. In $10^{\text {th }}$ item we have: ministry of housing and urban development by the aim of creating necessary facilities, banks can build cheap residential units to develop housing and according to $11^{\text {th }}$ item, banks can buy costumers stated property and lease them to costumers in order to create necessary facilities.(Jamshidi 2013)

So what we mean by leasing in Reba-free banking regulation is: obtaining costumers needs when they need initial materials and tools in production and housing units.

Therefore leasing items are:

1) Initial material, spare parts and tools

2) Means of machine production and installations

3) Durability of consuming goods made in the country

4) Housing.

\section{How to pay back:}

1) Receipt the sale price in one installment at the end of a period

2) Receipt the payment equally and consecutively for example monthly.

3) Receipt the payment after a period of waiting equally.

4) Receipt the payment uncoordinatedly.

5) Receipt the payment step by step.

\section{Chapter three: Self trades}

Self means buying something in advance according to instruction pecuniary. Buy the production in advance in order to provide a part of capital by cash is called Self.

\section{A) General conditions of Self}

According to $13^{\text {th }}$ item of Reba-free banking regulations, banks can buy some products in advance.

Self is a short time facility, mostly one year, and banks are allowed to buy something which is:

1) Produced by requesting units

2) Don't run fast.

3) Can be bought easily.

\section{B) How to grant facilities:}

Self is used when production units lack money but they have enough of initial material and spare parts and occasionally this problem is temporary and items below should be considered and evaluated to grant these facilities: (Jamshidi 2013)

a) Getting to know the unit.

b) Ensure business reputation and timely fulfillment of promises.

c) Evaluate the financial situation of production units according to following aspects:

1) Evaluate the financial state in the unit and making sure about lack of money.

2) Evaluate the amount of money which is needed.

3) Compare the price of the product which the same product.

4) calculate the period which the unit needs financial support and it is going to support itself.

5) Evaluate the amount of raw material for manufacturing. 


\section{C) Banking in Self}

Banks should sell the goods as soon as possible and write the expenses like transportation, storing and insurance to get them from customers.

\section{D) Differences between self and debt purchase}

In Self, bank buy goods an advance directly but in debt purchase it doesn't interfere in operation. In Self goods should have special conditions (like durable goods) but in doubt purchase, goods condition is never a factor.

Chapter 4) Morahebe

Morahebe is a trade which sales person announces the exact price of something and then asks for some interest.(Najafi 1994)

B) Parts of Morahebe

1) Two sides of trade: they are sales person and costumer who both reach maturity.

2) Affirmation and acceptance:

This contract can be concluded by customers and sales person desire.

3) Exchanges:

In Morahebe exchanges are goods and money.

\section{c) Duration}

Morahebe's duration can be short time, medium and long time according to good's lifetime.

This is at most five years which is extendable for more 2 years bye council permission.

\section{d) How to pay back}

It can be done by cash, credit or equal or unequal leasing in certain expiries.

e) Payment in advance

Banks should receive some money as a payment in advance to give them facilities

\section{f) Price of contract}

Price of Morahebe will be according to the final price and agreed bank interest.(Jamshidi 2013)

\section{Chapter five: Estesna}

Estesna or built order contract, is between two people to produce a special kind of good or do a special project which its price will be paid by cash or regular leasing.(Nazar poor 2005)

\section{c) Duration}

Estesna's duration can be short time, medium and long time according to good's lifetime.

This is at most 4 years which is extendable by council's permission.

\section{CONCLUSION}

Getting Reba by banks is banned in Islam and there are some limitations in Reba-free banking, which we can use some Reba-free methods to remove these limitations and challenges like they are using them in some Islamic countries like Malesia. Reba can cause injustice, poverty and scandal in society.

There are some solutions to develop and increase production and fulfill economic justice and public welfare in Islamic law according to interest omitting of banking and make use of Islamic contracts.

Among the contracts we studied, Garzolhasaneh can reduce poverty in society. For debt purchase, a person needs to have a current account in bank because business men have to use their bank accounts regularly. So an active bank account is the most important factor in granting facilities. We can conclude that if banks operate well in both observation and granting facilities, debt purchase can be an accepted and very useful contract. Because in this kind of contract banks give their property to the customer and use noted contract financially. So discussion and omission of Reba from this contract has been done by Islamic juries consult.

\section{REFRENCES}

AbolfazlDelghandi,2012, study of financial and accounting instruction of Reba-free banking, essays of 16th Islamic banking gathering.

Ali asgharHedayati,2002, inter banking operation, Tehran,banking institute.

Ali asgharHedayati,2007, bankong teaching center of central bank of Islamic Republic of Iran.

JafariLangrudi,Mohammad Jafar, 1999, expanded in law terminology,GhanjeDanesh,Tehran.

Mohammad hassanNajafi,1983, JavaherolKalam fi sharhsharaeEslam.

Mohammad HassnNajafi,1994,javaherolkalam.

Mohammad taghiNazarpoor,2005, Estesna valuable papers,number 20. 